\title{
Appendix III
}

\section{Counterparties to DTCs and TIEAs}

(All data extracted from the relevant government databases and the OECD Assessment)

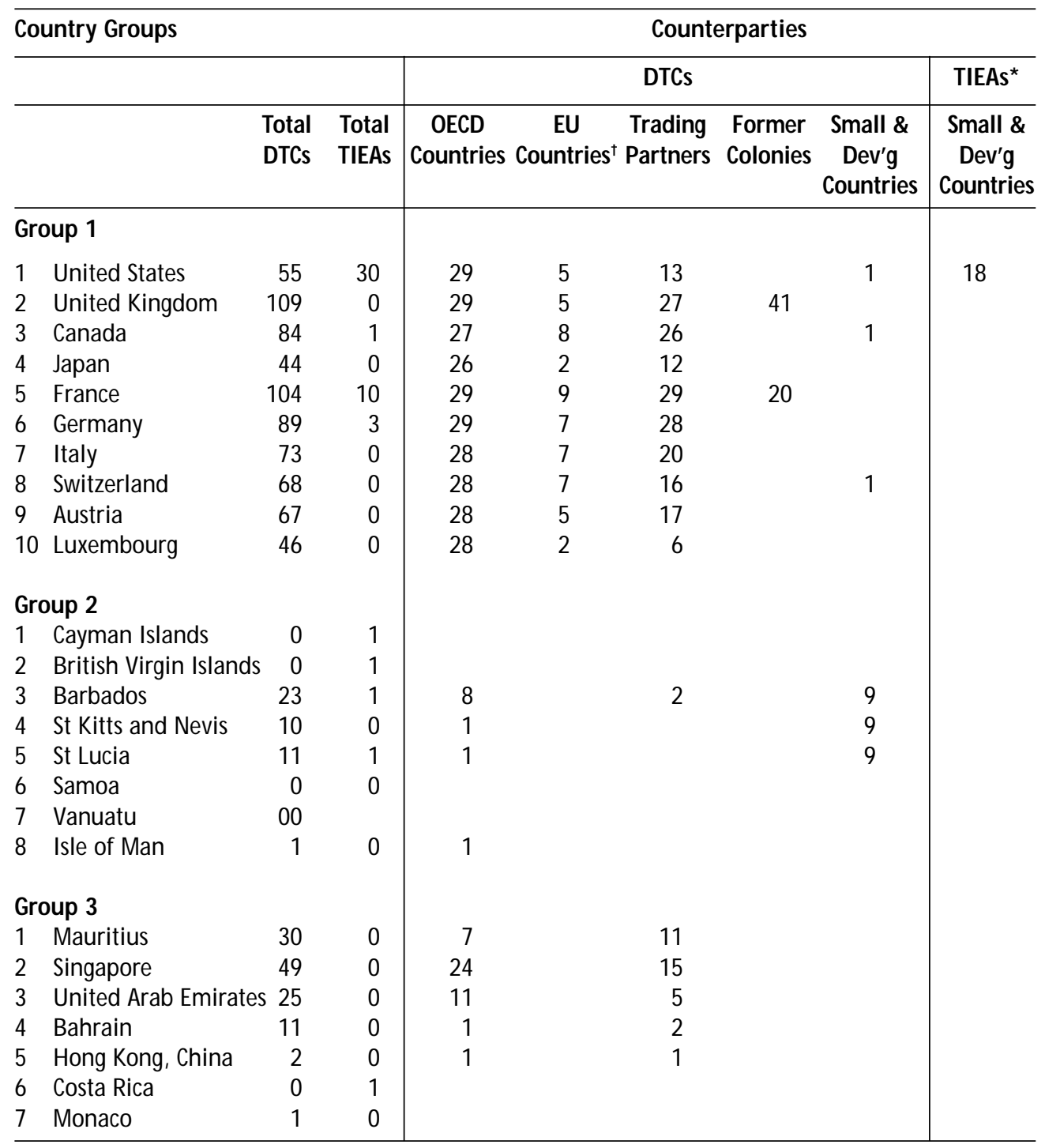

Small and developing countries indicates countries with population of less than 300,000 , which are not former colonies.

*TIEAs in this context means 'stand-alone' TIEAs, i.e. not supported by a DTC.

${ }_{\dagger}$ Countries which are members of the EU, but not of the OECD. 


\section{Notes}

1 OECD, 'Tax C o-operation: Towards a Level Playing Field - 2006 A ssessment by the Global Forum on Taxation' (14 A ugust 2006) <http://www.oecd.org/document/60/0,2340,en_2649_37427_36791868_1_1_1_ $37427,00$. html>

2 Examples of this include the anti-trust laws in the USA and the Competition Act in the UK, as well as the European Competition Directives.

3 The ITIO is a group of small and developing countries which work for a 'level playing field in the trade in services', 23 July $2006<w w w . I T I 0$.org> The ITIO's Proposal for the Level Playing Field (23 July 2006) $<$ http://www.itio.org/documents/Levelling_the_playing_field.htm>

4 W. Leibfritz, J. Thornton and A. Bibbee (1997). 'Taxation and Economic Performance', OECD/G D (97) 107, OECD Economics Department W orking Paper N 0. 176; R. G riffith and A . Kemm (2004). 'W hat H as Been the Tax Competition Experience of the Last Twenty Years?', Institute of Fiscal Studies and U niversity C ollege London, W P04/05; R. Teather (2005). 'The Benefits of Tax Competition', Institute of Economic A ffairs, London.

5 O ECD (1998). H armful Tax Competition: A n Emerging G lobal Issue, p. 7, para. 2 (14 A ugust 2006) <http:// www.oecd.org/dataoecd/33/0/1904176.pdf>

$6 \quad O E C D$ (note 5$)$.

7 OECD (note 5, A nnex II).

8 Robert Kudrle (2005). "US Defection from the OECD "H armful Tax Competition" Project: Rhetoric and Reality', H ubert H umphrey Institute, U niversity of M innesota.

9 Kudrle (note 8).

10 ITIO (2003). 'Levelling the Playing Field', Proposal by the ITIO to the OECD G lobal Tax Forum, 14-15 0 ctober 2003, Ottawa, Canada.

11 Kudrle (note 8); M . Langer (2002). 'T he O utrageous History of C aribbean Tax Treaties with OECD M ember States', Tax N otes International, 10 June 2002, pp. 1187-99; G. Rawlings (2005). 'Responsive Regulation, Multilateralism, Bilateral Tax Treaties and the Continued A ppeal of O ffshore Finance Centres', working paper N o. 74, Centre for Tax System Integrity Research, School of Social Sciences, A ustralian National U niversity, $C$ anberra.

12 OECD (2000). 'List of 35 "Tax H avens"' (12 A ugust 2006) <http://www.oecd.org/dataoecd/60/11/2664514. pdf>. Six countries threatened with being 'blacklisted', but which made political commitments to enter into EOI upon request agreements, were excluded from this list; they were Bermuda, Cayman Islands, Cyprus, Malta, M auritius and San M arino.

13 For the six countries, see note 12.

14 The jurisdictions included A ruba, Bahrain, Isle of $M$ an, $N$ etherlands A ntilles and the Seychelles (OECD, 2001, \#420, para. 22).

15 This narrowing of the OECD's scope may arguably be related to the change in the stance of the U SA following the election of President Bush. Treasury Secretary $O$ ' $N$ eill's Statement on OECD Tax Havens, U S O ffice of Public A ffairs (27 O ctober 2006) < http://www.ustreas.gov/press/releases/po366.htm>

16 O EC D (2002). 'A greement on Exchange of Information on Tax M atters' (13 A ugust 2006) <http://www.oecd. org/dataoecd/15/43/2082215.pdf>

17 OECD (2006). N ote 1, A nnex III.

18 D. Wise (1982). 'International Banking Facilities and the Future of Off-Shore Banking', Fletcher Forum, p. 300.

19 Rawlings, see note 11.

20 R. Johns (1983). Tax H avens and 0 ffshore F inance, Pinter, London, p. 29.

21 R. A liber (1979). 'M onetary A spects of O ffshore M arkets', C olumbia Journal of W orld Business, 14(3), p. 19.

22 F. Edwards (1981). 'The new "International Banking Facility": a study in regulatory frustration', Columbia Journal of World Business, 16, p. 6.

23 A . Leyshon (1992). 'The Transformation of Regulatory O rder: Regulating the G lobal Economy and Environment', G eoforum, 23(3), p. 260.

24 OECD (note 23). Liquidity refers to the ability to buy or sell a particular item relatively quickly without causing a significant movement in the price.

25 O ECD (1998). 'H armful Tax Competition: A n Emerging G lobal Issue', p. 21, para. 48 (14 A ugust 2006) $<$ http://www.oecd.org/dataoecd/33/0/1904176.pdf>

26 Leibfritz et al; G riffith and Kemm; and Teather (note 4). 
27 The justification given was that residents of non-treaty countries had used the $C$ aribbean treaties to reduce withholding taxes on investment into the OECD countries. Langer (note 11).

28 A ny potential or perceived abuse of these treaty extensions arguably could have been adequately addressed by well drafted limitation on benefit provisions (LOB); see Langer (note 11).

29 R. Keohane and J. N ye Jr, 'The Club Model of Multilateral Cooperation and Problems of Democratic Legitimacy', paper prepared for the A merican Political Science Convention, Washington, DC, 31 A ugust3 September 2000.

30 D. Wise (1982). 'International Banking Facilities and the Future of Off-shore Banking', 6 Fletcher Forum, p. 312.

31 A. H udson, 'Beyond the Borders: G lobalisation, Sovereignty and Extraterritoriality' (15 A pril 2000) <http:// www.alanhudson.org.uk/borders.pdf>

32 R. O 'Brien (1992). G lobal Financial Integration: The End of G eography, R oyal Institute of International A ffairs, London, p. 1.

33 Jeffrey Owens (2002). 'The OECD work on Tax Havens', presented at the Friedrich Ebert Foundation Conference on 'M oney Laundering and Tax $\mathrm{H}$ avens - The H idden Billions for Development', OECD Centre for Tax Policy and A dministration, p. 6.

34 W.F. Wechsler (2001). 'Follow the M oney', Foreign A ffairs, 80, p. 40.

35 FATF (2006). 'Summary of the Third M utual Evaluation Report on A nti-M oney Laundering and Combating the Financing of Terrorism: U nited States of A merica', from para. 36; FATF (2005). 'Summary of the Third Mutual Evaluation Report A nti-M oney Laundering and Combating the Financing of Terrorism: A ustralia' (22 A ugust 2006) <www.fatf-gafi.org/dataoecd/22/38/35509034.pdf>; FATF (2005). 'Summary of the Third M utual Evaluation Report A nti-M oney Laundering and Combating the Financing of Terrorism: Ireland' (22 A ugust 2006) <www.fatf-gafi.org/dataoecd/63/29/36336845.pdf>

36 (IM F) (2004). 'O ffshore Financial Centers: The A ssessment Program - A n U pdate' (16 A ugust 2006) <http:// www.imf.org/external/np/mfd/2004/eng/031204.pdf>

37 J. Nye Jr (2003). 'The "Democracy Deficit" in the Global Economy: Enhancing the Legitimacy and A ccountability of G lobal Institutions', Task Force Report \#57 - The Trilateral Commission (23 July 2006) <http://www.trilateral.org/projwork/tfrsums/tfr57.htm>

38 The OECD published a list in June 2000 of countries which would be 'blacklisted' as 'havens' unless they made political commitments to comply with the wishes of the OECD member countries (14 A ugust 2006) <http://www.oecd.org/dataoecd/60/11/2664514.pdf> The OECD subsequently published a 'blacklist' of 'uncooperative tax havens' (2002) (14 A ugust 2006) <http://www.oecd.org/document/19/0,2340,en_2649_ 201185_2082323_1_1_1_1,00.html>

39 Society of Trust and Estate Practitioners (ST EP) (2005). 'D econstructing N ational Tax Blacklists: Removing the $\mathrm{O}$ bstacles to C ross-Border Trade in Financial Services', R eport prepared for the Society of Trust and Estate Practitioners, presented at the 'Beyond the Level Playing Field?' symposium, London, 19 September 2005.

40 STEP (note 39).

41 Commonwealth Secretariat (2006). 'Developmental Implications of Anti-Money Laundering Taxation Regulations', paper prepared by J.C. Sharman, presented at the Commonwealth Finance M inisters M eeting, Sri Lanka 12-14 September, 2006 (28 0 ctober 2006) < http://www.thecommonwealth.org/Shared_A SP_ Files/U ploadedFiles/60F584BC -D 173-40B2-A 126-05DCC 68DC6E7_FM M (06)17.pdf>

42 OECD (2006) (note 1), p. 53.

43 ITIO (2003). 'Levelling the Playing Field', Proposal by the ITIO to the OECD G lobal Forum on Taxation, Ottawa, Canada, 14-15 O ctober 2003.

44 Ibid., closing statement by the co-chairs (13 0 ctober 2006) < http://www.oecd.org/document/0/0,2340,en 2649_33745_16643264_1_1_1_1,00.html>

45 OECD countries included in this sub-group are: A ustralia, France, G ermany, Japan, and U SA. N on-OECD countries include the Bahamas, C ayman Islands, Isle of M an, Jersey, M auritius, Panama, St Kitts $\&$ N evis and Samoa. The sub-group also includes representatives of the OECD Secretariat and the Commonwealth Secretariat.

46 OECD (2004). 'The OECD'S Project on H armful Tax Practices: the 2004 Progress Report' (Berlin Report), p. 12, para. 21 (14 A ugust 2006) <http://www.oecd.org/dataoecd/60/33/30901115.pdf>

47 Berlin Report (note 41), para. 8.

48 Berlin Report (note 41), para. 3.

49 The survey sought to identify legal and administrative frameworks for exchange of tax information in all OECD countries, all non-OECD countries originally targeted in the 2000 'blacklists' and non-OECD financial centres not originally targeted in the $\mathrm{H}$ armful Tax Competition Initiative. 
50 Progress Towards a Level Playing Field: O utcomes of the OECD Global Forum on Taxation, Melbourne, 15-16 N ovember 2005, para. 8(v) (13 0 ctober 2006) http://www.oecd.org/dataoecd/28/55/35670025.pdf

51 FAT F, 'FATF A ssesses the U nited States System for Combating M oney Laundering and Terrorist Financing' <http://www.fatf-gafi.org/document/23/0,2340,en_32250379_32237217_37101591_1_1_1_1,00.html>; G eneral A ccounting O ffice; M inimal O wnership Information is Collected and A vailable ( $1 \overline{1} \bar{O}$ ctober 2006 )<http://www.gao.gov/new.items/d06376.pdf>

52 The World Bank statistical resources (14 A ugust 2006): Gross Domestic Product (PPP GDP) <http://site resources.worldbank.org/DATA STATISTICS/Resources/G DP_PPP.pdf>; G ross N ational Income per Capita (GNIPC) <http://siteresources.worldbank.org/DATA STATISTIC S/Resources/GNIPC.pdf>; Population <http://siteresources.worldbank.org/DATA STATISTIC S/Resources/PO P.pdf>

53 O ECD (2006), Table A 3, p. 85 (note 1).

54 Internal Revenue Services, Income Tax Treaties (14 A ugust 2006) <:http://www.irs.gov/businesses/ international/article/ 0, id $=96739,00$.html $>$

55 These countries include the British Virgin Islands, the M arshall Islands, St Lucia, Cayman Islands, Turks and Caicos Islands, M ontserrat, A nguilla, Jersey, Isle of Man, Grenada, Guernsey, Dominica, the Bahamas, Bermuda, Barbados, A ruba, the N etherlands A ntilles and A ntigua and Barbuda. The original OECD list of target countries in 2000 (14 A ugust 2006) < http://www.oecd.org/dataoecd/60/11/2664514.pdf>

56 This is evidenced by Trinidad, Jamaica and M exico, with M exico al so being an O ECD country.

57 General Accountability Office (2006). 'Company Formations: Minimal Ownership' (14 A ugust 2006) $<$ <ttp://www.gao.gov/new.items/d06376.pdf>

58 FATF (2006). 'Summary of the Third M utual Evaluation Report on A nti-M oney Laundering and Combating the Financing of Terrorism: U nited States of A merica', p. 9.

59 World Bank statistical resources (note 44).

60 OECD 2006 A ssessment (note 45).

61 HM Revenue and Customs (22 A ugust 2006) <:http://www.hmrc.gov.uk/international/treatiesb.htm>

62 W orld Bank statistical resources (note 44).

63 OECD 2006 A ssessment (note 45).

64 Department of Finance, Canada (22 A ugust 2006) < http://www.fin.gc.ca/treaties/cndtxtreat_e.html>

65 W orld Bank statistical resources (note 44 ).

66 OECD 2006 A ssessment (note 45).

67 W orld Bank statistical resources (note 44 ).

68 OECD 2006 A ssessment (note 45).

69 World Bank statistical resources (note 44 ).

70 OECD 2006 A ssessment (note 45).

71 World Bank statistical resources (note 44).

72 OECD 2006 A ssessment (note 45).

73 World Bank statistical resources (note 44 ).

74 OECD 2006 A ssessment (note 45).

75 World Bank statistical resources (note 44 ).

76 OECD 2006 A ssessment (note 45).

77 W orld Bank statistical resources (note 44 ).

78 OECD 2006 A ssessment (note 45).

79 The W orld Bank categorises countries with a per capita income of over $\$ 10,726$ per annum as 'high-income' countries (14 A ugust 2006) <http://siteresources.worldbank.org/D ATA STATIST IC S/R esources/G N IPC.pdf>

80 World Bank statistical resources (note 44 ).

81 World Bank statistical resources (note 44 ).

82 IM F. 'C ayman Islands: A ssessment Supervision and Regulation of the Financial Sector' (14 A ugust 2006) <http://www.imf.org/External/Pubs/FT/SCR/2005/cr0591.pdf>

83 U nited $N$ ations (14 A ugust 2006) <http://esa.un.org/unpp/>

84 Development Planning U nit of the British Virgin Islands, 14 A ugust 2006 <http://www.dpu.gov.vg/Plans/ NIDS/PresentSituation.htm>

85 W orld Bank statistical resources (note 44 ).

86 The World Bank categorises countries with a per capita income of $\$ 3,446-\$ 10,725$ per annum as 'upper middle-income' countries (14 A ugust 2006) < http://siteresources.worldbank.org/DATA STATISTICS/ Resources/GNIPC.pdf>

87 W orld Bank statistical resources (note 44). 
OECD 2006 A ssessment (note 45).

89 Barbados M inistry of Finance (22 A ugust 2006) <: http://www.treasury.gov/offices/tax-policy/library/barbados protocol.pdf>

90 World Bank statistical resources (note 44 ).

91 OECD 2006 A ssessment (note 45).

92 World Bank statistical resources (note 44 ).

93 OECD 2006 A ssessment (note 45).

94 World Bank statistical resources (note 44).

95 OECD 2006 A ssessment (note 45).

96 W orld Bank statistical resources (note 44 ).

97 OECD 2006 A ssessment (note 45).

98 W orld Bank statistical resources (note 44 ).

99 OECD 2006 A ssessment (note 45).

100 W orld Bank statistical resources (note 44 ).

101 OECD 2006 A ssessment (note 45).

102 M auritius M inistry of Finance and Economic Development (22 A ugust 2006) <http://www.gov.mu/portal/ sites/ncb/fsc/tax.htm>

103 W orld Bank statistical resources (note 44 ).

104 OECD 2006 A ssessment (note 45).

105 Inland Revenue A uthority of Singapore (23 A ugust 2006) < http://www.iras.gov.sg/ESV Portal/tax_ resources/treaties/index.asp>

106 World Bank statistical resources (note 44).

107 W orld Bank statistical resources (note 44).

108 OECD 2006 A ssessment (note 45).

109 W orld Bank statistical resources (note 44).

110 OECD 2006 A ssessment (note 45).

111 W orld Bank statistical resources (note 44 ).

112 OECD 2006 A ssessment (note 45).

113 Inland Revenue Department of $\mathrm{H}$ ong Kong (24 A ugust 2006) < http://www.ird.gov.hk/eng/tax/edu.htm>

114 The World Bank statistical resources (note 44 ).

115 OECD 2006 A ssessment (note 45).

116 The World Bank categorises countries with a per capita income of over $\$ 10,726$ per annum as 'high income' countries (14 A ugust 2006) http://siteresources.worldbank.org/DATA STATISTIC S/R esources/G N IPC.pdf>

117 World Bank statistical resources (note 44).

118 OECD 2006 A ssessment (note 1); Département des Finances et de l'Economie (12 A ugust 2006) < http:// www.gouv.mc/devwww/wwwnew.nsf/1909\$/495e638995f98929c1256f5e0052c441gb?0 penD ocument\& 4G b>

119 IMF (note 34).

120 UNCTAD (2002). 'Experiences with Bilateral and Regional A pproaches to Multilateral Cooperation in the A rea of Long-Term Cross-Border Investment, Particularly Foreign Investment', Trade and Development Board, Commission on Investment, Technology, and Related Financial Issues, Expert M eeting in Geneva, 12-14 June 2002, p. 5 (26 A ugust 2006) <http://www.unctad.org/en/docs/c2em11d2_en.pdf > In September 2005 the OECD reported that there are more than 2500 bilateral tax treaties in force around the world ( 3 September 2006) http://www.oecd.org/document/11/0,2340,en_2649_33747_35318475_1_1_1_1,00.html

121 OECD 2006 (note 1), p. 15 para. 31. Sixty-five of the approximate 150 countries are included in this report.

122 In this context other benefits were negotiated, such as the $C$ aribbean Basin Initiative.

123 Langer (note 11), p. 7.

124 OECD 2006 report, p. 17, para. 31.

125 ITIO (2005). 'Levelling the Playing Field', OECD G lobal Tax Forum, M elbourne, 15-16 N ovember, p. 3.

126 ITIO (2006). 'G lobal Transparency, Exchange of Tax Information and Small N ations - M uch H as Been Done, But M ore is N eeded to Ensure a Level Playing Field' (22 A ugust 2006) <http://www.itio.org/documents/itio_ oecd_final.pdf\#search $=\% 22$ 'vicious $\% 20$ circle'\%22>

127 R. Bäldwin and M. Cave (1999). U nderstanding Regulation: Theory, Strategy, and Practice, Oxford U niversity Press, Oxford, p. 180.

128 OECD (2004). 'The OECD's Project on Harmful Tax Practices: The 2004 Progress Report' (Berlin Report), p. 12, para. 21 (14 A ugust 2006) <http://www.oecd.org/dataoecd/60/33/30901115.pdf> 
129 ITIO) (2005). 'Levelling the Playing Field' (22 A ugust 2006) <http://www.itio.org/documents/melbourne itio_oecd_paper_nov_05.pdf\#search=\%22fair\%20competition\%20between\%20all\%20countries\%22>

130 OECD 2006 (note 1), p. 52.

131 Meeting of the OECD Council at the Ministerial Level (2006). (22 A ugust 2006) <http://www.oecd.org/ dataoecd/42/9/36686180.pdf>.

132 OECD, Third Meeting of the OECD Forum on Tax Administration, 14-15 September 2006, Final Seoul Declaration (13 0 ctober, 2006) <http://www.oecd.org/dataoecd/38/29/37415572.pdf>

133 OECD 2006 (note 1) pp. 7-8.

134 J. Rawls (2003). Justice as Fairness: A Restatement, $\mathrm{H}$ arvard U niversity Press, Cambridge, p. 6. 